\title{
Innovation, Competition and Financial Vulnerability in Economic Development ${ }^{1}$
}

\author{
LEONARDO BURLAMAQUI \\ JAN KREGEL ${ }^{2}$
}

\begin{abstract}
A bstract: The financial sector has been viewed traditionally as either providing the "oil" for the "wheels of commerce" or as a parasite on the real sector of the economy where real productivity gains provide for increasing real wages and per capita incomes. The present paper takes a different route and attempts to an analysis of financial institutions on a par with the production sector of the economy. It also develops a link which amalgamates "the knowledge-based" perspective on firms' operations with Schumpeterian financial leverage to exploit productivity enhancing innovations, and M insky's tendency towards financial fragility. The analysis also leads to some policy recommendations concerning financial regulation, risk management and financial institution's building.

Key-words: Business O rganization, Competition in Finance, financial Innovation, Financial Fragility, Development Policies.
\end{abstract}

JEL Classification: F, F02, F37, F4, 020

\section{INTRODUCTION}

This paper uses the theoretical traditions associated with Schumpeter, Penrose and $M$ insky to examine the role of innovation and competition in finance and in

\footnotetext{
${ }^{1}$ This paper is part of a larger research project on Institutions, Organizations, Strategies and Development, funded by the Ford Foundation N.Y. and Rio de Janeiro (Grant 1035-0619-1). The authors would like to thank the Foundation for its financial support

2 Professor of the Law Graduate Program at Candido M endes University, and Adjunct Professor of Political Economy at the State University of Rio de Janeiro; and Senior Inter regional Adviser, United $\mathrm{N}$ ations Conference on Trade and Development, respectively. . E-mails: Iburlamaqui@globo.com and kregel-ny@un.org. Submitted: February 2004; Accepted: A pril 2004

${ }^{3} \mathrm{M}$ insky, while a noted Post Keynesian, often commented on the affinity of Schumpeter's and Keynes' views on finance; see M insky (1986, p.113) and M insky (1990).
} 
economic growth. ${ }^{3}$ From that perspective, two aspects of the role of financial firms competition and grow th are important. $O$ ne is the crucial role played by financial firms in providing manufacturing firms with the credit they require to engage in the competitive process of creative destruction. The second is the competitive behavior of financial firms themselves, which transforms financial markets and, in turn, affects the ability of all firms to finance new innovations. The uncertainty and risk that underlie $M$ insky's financial fragility hypothesis are seen to result from Schumpeterian innovation, and spur further innovations. Knowledge-based innovation is a key strategic response to an environment of uncertainty and financial instability: Furthermore, financial innovations that facilitate the financing of innovation in business tend to decrease transparency concerning the risks being borne in the system, raising the possibility of ever-increasing financial risks and ever-decreasing understanding of the extent of these risks.

The structure of the paper is the following. The next section briefly sketches out two approaches to the firm inspired by the ideas of Schumpeter-Penrose and $M$ insky. The two sections that follow then summarize Schumpeter's and M insky's ideas about the role of finance in economic dynamics, in light of these ideas about the firm. Competition and innovation in the financial sector are discussed, follow ed by attention to the impact of globalization, especially on developing nations. A brief discussion of policy implications and a short summary conclude the paper.

\section{SCHUM PETER, PEN ROSE AND M INSKY ON THE FIRM : KNOWLEDGE-BASED AND CASH-FLOW APPROACHES}

\subsection{The Knowledge-B ased A pproach to the Firm}

The late (1942) Schumpeter understood capitalism as an historical process whose defining feature is not equilibrium (as in the neoclassical canon), but change. Chandler (1990) validates Schumpeter's conception by providing historical chronicles that illustrate how firms compete in market settings. He shows that firms engage in ongoing struggles not simply to survive, but to achieve and hold dominant market positions. In these struggles, continuous change and unforeseen circumstances are the most significant threats to firms' survival (Rosenberg:1994).

A key element of the firm, emphasized by Penrose, Chandler and by other theorists in different ways, is the creation and strategic management of knowledge-based resources. These resources include individual employees, teams, processes, and technologies. Some firm resources are acquired through armslength purchases (as when new employees are hired); others are developed through processes internal to the firm. Firm managers' strategic management involves decisions about how to use existing firm capabilities, how to create new capabilities, and how to respond to uncertainty.

Different authors exploring the knowledge-based theory of firm organization have emphasized different aspects of firm behavior. Chandler views manage- 
rial organisation itself as a production technique that confers "first mover" advantages. Edith Penrose (1959 [1995]) emphasizes that firms are not only more efficient in organizing factors, they are more efficient in developing new techniques which cope with changes in uncertain environments. They accomplish this by creating internal environments - "pools of relative certainty" - capable of combining and coordinating responses to external volatility, and thereby generating endogenous innovations. These are just two ideas of many that have been proposed regarding how firms react to changing, uncertain environments. A fuller accounting of these responses would include adaptations in the existing management and organization of production, and changes in the organisation itself (Best, 1990, 2001, Lazonick, 1991, Baumol, 2001 and Chandler et al, 1997).

In any event, firms that survive invariably innovate - that is, they exploit opportunities for change by applying new ideas, methods, or combinations of resources. Further, the innovation process is ceaseless. The very success of firms' reactions to competitive challenges acts to reinforce uncertainty and instability, calling forth new reactions and innovations and leading to self-perpetuating economic change. Firms thus compete continuously for market advantages, with asymmetric results: success for some, with strengthened technological and organizational capabilities, and above-average (their own) past profits; failure for other firms, which either disappear or are reduced to marginal activities. Schumpeter, whose core ideas are elaborated by these theorists, put it as follows: "to escape being undersold, every firm is compelled to follow suit, to invest, and to accumulate" (Schumpeter: 1942 [1992] chapter 3: 32).

Competition is therefore the struggle for survival and growth in a structurally uncertain environment ( $\mathrm{N}$ elson and W inter: 1982, parts 2 and 5). The profits that result from dominant market positions are always under threat from imitative strategies or other firms' innovative behaviors; they can only be maintained by continuous product differentiation and productivity enhancement.

\subsection{The Cash-Flow Approach to the Firm}

M insky's analysis of the firm emphasizes the firm's cash flows and their sustainability in light of the borrowing required to acquire assets. M insky defines three balance sheet configurations: hedge, speculative and Ponzi. The asset side of a "hedge" balance sheet produces expected cash inflows that always exceed their financing costs and operating expenses, including dividends, by a margin capable of absorbing any unforeseen changes in cash inflows and outflows. If the liquidity cushion covers, say, 2.33 standard deviations of the historical data on past gross operating returns, then the firm would be unable to meet its cash flow commitments on average only one time in a hundred. A company that can meet its payments with $99 \%$ probability is close to what a banker considers risk-free - a hedge unit.

As the cushion of safety declines, the probability of being unable to meet cash flow commitments rises; at some point it will be $99 \%$ probable that in some 
future periods the firm's cushion will not be sufficient to meet its payment commitments. N onetheless, the cumulative cushion over the life of the loan should be sufficient to cover them; so the project has a positive expected net present value. This is what M insky calls a "speculative" financing position: both the banker and the borrower are speculating that by the end of the project there will be enough money to repay the loan, despite some shortfalls along the way. A bank loan officer with good expertise in credit assessment will accept such loans. ${ }^{4}$

Finally, when the cushion of safety is non-existent and there is a high probability of shortfalls in nearly every period, the firm may have to borrow additional funds just to meet current commitments. M insky calls this "Ponzi" financing, making reference to a well-known post-war pyramid investment scheme. These are companies that must increase their borrowing just to stay in business; according to standards of good credit assessment, bankers should not lend to such units under any circumstances (K regel, 1997c). For Ponzi units, profits expectations are based solely on the possibility of the resale of assets at higher prices.

Building on Keynes and Schumpeter's analytical framew orks, M insky argues that in a capitalist economy in which the future is subject to unforeseen changes, the value of hedge and speculative financing positions changes with variations in the overall macro behavior of the economy. For example, a change in economic policy that produces a rise in interest rates affects firms' financing positions in two ways: it reduces the present values of the expected cash flows from operating projects; and it increases the cash flow commitments for financing charges if interest rates are set on an adjustable or rollover basis.

\section{A SCHUM PETERIAN CAPABILITIES VIEW OF FIN ANCE, IN NOVATION, AND GROWTH}

The innovative competitive reactions discussed above, insofar as they require additional expenditures, all can be undertaken only if they can be financed. This was a key link in Schumpeter's vision of the process of economic growth. Schumpeter considered finance as the motor force of industry; only with financing can firms appropriate the resources necessary to introduce innovations (Schumpeter, 1934 [1997]), ch. 3, and 1939 v. 1, ch. 3).

Enlarging Schumpeter's perspective involves identifying the characteristics of banks or of other financial firms that lead them to play this role in the innovation/growth process. This means accounting for the existence of banks and other financial firms within the economy. In the contemporary economic literature, many different rationales for the existence of banks have been established. 0 ne set of explanations attributes banks' existence to the advantages of large-scale operations per se. Banks may arise because they specialize in the investment of depositors'

\footnotetext{
${ }^{4}$ In M insky's terms, Schumpeterian entrepreneurs are always speculative units, and true Schumpeterian entrepreneurs are quasi Ponzi units.
} 
funds, and thus are more efficient than households in acquiring information about potential investment opportunities and hence in earning returns through the placement of savings. Banks' existence can also be explained by their scale advantages in monitoring the performance of borrowers. A more recent explanation attributes banks' existence to their involvement in financial engineering processes, especially the unbundling of large indivisible investments for sale to households. ${ }^{5}$

These approaches, while elaborating on banks' use of scale economies in achieving informational advantages, do not explain the unique role that Schumpeter attributed to the institutions financing the innovation process. The above explanations could also be used to explain the existence of money market mutual funds, which offer transactions and transfer facilities to their clients but make no loans (M ayer 1974), or the existence of collateral-based lenders. It might be more useful to begin with the two archetypal activities of the commercial bank: credit creation through lending to business firms in support of productive economic activity; and the proprietary purchase and sale of financial assets to benefit from pricing differentials that occur at a point in time or over time. These two activity types are significant from a Schumpeterian perspective, since the form aims to increase total income and wealth, while the latter has no impact on the absolute level of income

Productive lending in the sense suggested by Schumpeter in his Theory of Economic Development (published in its first, German, edition in 1911) provides firms with access to the resources they require to undertake production. Lending of this type requires particular knowledge of the production process, costs, and future market conditions for the products produced by each firm to which credit is extended and thus of its prospects for repayment. It facilitates the activities of the high return, knowledge-absorbing sectors that produce dynamic industrial growth (in the same vein, see M insky: 1990, pp. 60-65).

$M$ anagement of the bank's proprietary investment portfolio, by contrast, requires information about the formation and evolution of prices in various securities markets; this process may have no relation at all to the information required to make decisions on lending to industrial borrowers. The motivation for such activity is, according to the theory of efficient markets, based on the idea that arbitrage in free competitive markets can eliminate any differences in the prices of identical titles to expected future income streams traded as financial assets. The impact of financial arbitrage is limited to the static efficiency of the competitive market process: it forces uniformity in market prices and helps allocate given resources to their optimal risk-return combinations. The successful arbitrageur profits from the elimination of such differences by being early to recognize them; by contrast, the successful borrower profits from the organizational or managerial innovations that grant the firm a dominant market position.

Both types of knowledge-based activities are carried out by many commercial banks. When carried to extremes, they are reflected in the two basic organi-

\footnotetext{
${ }^{5}$ For a recent summary of this literature, see Freixas and R ochet (1997).
} 
zational forms characteristic of financial institutions: relationship or house banking; and competitive market-based activity, sometimes know n as "transactional" banking. In the former, the knowledge advantage possessed by the bank involves its clients' production activities, and the potential profitability of these activities in producing the earnings needed to pay debt service and repay principal. This type of bank operation is usually associated with German Kreditbanks; US investment banks have historically played a similar role, although in a slightly different context and on a reduced scale (cf. M adeleine, 1943, R obertson, 1955, 1964, $\mathrm{H}$ ammond, 1967). Indeed, German banks often employed engineers and scientists to help evaluate the technology and thus the long-term prospects of borrowers to fully exploit knowledge-based advantages.

O ne characteristic of relationship banking is that it does not permit free market competition among banks for business; no firm would willingly provide the proprietary information required for a banking relationship to a financial institution if it thought that institution might be working for a competitor in the near future. For full information sharing between bank and borrower, confidentiality in the treatment of information must be present; this implies the exclusivity of the services provided by the bank. N either would a firm be willing to offer all the information necessary to allow permit a number of competing banks to make competitive bids for its business. By contrast, financial arbitrage - the basis of most of the transactions activities of banks - is based on knowledge of particular characteristics of the payment flows represented by financial assets, the prices of these assets that prevail in the market, and/or the prices that other market participants expect to prevail at futures dates and places. 0 ne might say that the relationship bank is speculating on the nominal profitability of an innovative industrial process embodied in the firm that it is financing, while the transactional bank is speculating on its ability to identify anomalies in the efficient operation of the market mechanism and the on the capacity of market competition to eliminate these anomalies.

In this regard it is important to remember that although financial institutions have certain peculiar characteristics and function in a special regulatory environment, they are nonetheless business firms and compete much like other firms. So just as the industrial structure is driven by competition, financial institutions seek to earn profits from the exploitation and protection of the various knowledge-based advantages they have acquired. That is, organizational and production advantages will produce dominant competitive positions which can only be challenged by firms capable of reproducing innovations, or of perfecting other techniques that are more attractive to the market and hence more profitable (Burlamaqui and Lagrota, 1998, part 5).

As al ready mentioned, in financial systems where main banks or house banks provide relationship services, there is a tacit agreement, as well as a practical imperative, that banks do not compete for business. By contrast, market-based systems, wherein the required knowledge involves markets or instruments, but not information about clients, present the possibility of financial innovations via rapid reverse engineering. This permits the competitive emulation that provides 
for eminently contestable markets. Financial institutions will compete for business by seeking to replicate the financial instruments and services that other institutions offers to their clients. Competition of this type can encompass either the direct confrontation of competitors or the expansion of activities into other sectors or areas of the production process. As the introduction of new information processing technology increases organizational capacity, and enhances economies of both scale and scope, financial firms can integrate additional services into their activities. The creation of financial firms capable of this activity requires the evolution and concentration of financial institutions and financial markets to a size that is sufficient to achieve similar economies of scale and scope. ${ }^{6} \mathrm{~N}$ ote that this growth in financial firms' capacity makes it possible for non-financial firms too to achieve greater economies of scale and scope.

\section{A M IN SKYIAN VIEW OF BANKS, FINAN CE AND LIQUIDITY}

For M insky, as well as for Schumpeter, debt financing is the core of the very logic of capitalist production. In exploring the link between finance and economic activity, $M$ insky shifts attention away from the problem of productive credit and focuses on the problems of liquidity and credit overexpansion. $\mathrm{H}$ is work belongs to the Post-K eynesian approach to economics, a perspective that takes money and finance (rather than technology or innovation per se) as the most important organizational features of capitalist systems. The Post Keynesian view emphasizes the crucial importance of uncertainty and liquidity preference in understanding the multiple rationalities for, and the volatility that guides, investment decisions; it also explores the implications of these elements for economic instability. M insky emphasizes the need to fully incorporate real world phenomena - and specially finance - into the core of economic analysis, so as to grasp the intrinsically unstable nature of capitalist economies.

M insky's "W all-Street Paradigm" develops a theory of endogenous macroeconomic instability by connecting the dynamics of debt structures and interest rates. In his vision, understanding money means understanding a vital process shaping a social evolution whose future course remains open-ended and contingent. In this sense, M insky's theory should be taken as an essentially institutionalist one, in the sense that he viewed the structure of the economic world - much as did his former teacher Schumpeter - not as immanent in some set of underlying data (such as endowments or technology) but rather as constituted by a set of key economic institutions. M oney was the most important of these. $\mathrm{H}$ is way of fleshing out that idea was to look at every economic unit - firms, households, governments and even countries - as though it was a bank balancing cash inflow generated by a stock of assets against cash outflows required to maintain the lia-

\footnotetext{
${ }^{6} \mathrm{M}$ ayer $(1988,1992)$ shows the impact of these changes in the organization of financial firms on the operation of financial markets.
} 
bilities created to acquire those assets. From that point of view, categories of activity such as production, consumption, trade and investment represent, first of all, exchanges of stocks of real and financial assets with particular monetary flow characteristics and attached conditions. To put it bluntly, money and finance are the most real aspects of capitalism, from everything else springs.

In this approach, the most basic element of the economy is cash flow, and the most basic constraint on economic behavior is the "survival constraint," which requires that cash outflow not exceed cash inflow if existing stock positions are to be maintained (M insky: 1978, 157). Because the exact coordination of payments is impossible, even this simple constraint involves finance. From that perspective, finance and financial relationships are fundamental because they oxygenate economic units, allowing them to purchase without previous savings; and they make growth and structural transformation possible, by providing current purchasing power to those who would use it to expand the boundaries of the system.

$\mathrm{H}$ owever, in M insky's thinking, finance has a double-edge quality. The other side of the "positive" roles mentioned above is that finance allows economic units to become illiquid in the present (by way of cash commitments) in exchange for the possibility of recovering liquidity (plus profitability) in the future; specifical$l y$, it permits these units to acquire assets whose expected cash-flows will exceed the cash commitments entered into to acquire them. Thus finance allows the undertaking of future commitments that may turn out to be impossible to fulfill. Failures of expectations realization then take the form of liquidity crunches, or in severe cases, of insolvencies and bankruptcies.

The subjectivity and volatility of expectations thus make financial asset prices more volatile than other prices in the economy (Keynes: 1936 [1983] chapter 12, Strange: 1998). Secondly, given the inherent volatility of financial asset values, liquidity provides an important "protective device" or "defensive strategy" to manage uncertainty, for two reasons. First, since money is the unit of account its value is less volatile and more certain in terms of other goods than other financial assets; thus it represents a refuge from price volatility. Second, it provides assurance that future cash commitments can be met with certainty. Thus firms whose incomes flows are subject to fluctuation may want to hold cash cushions to make sure that they can meet recurrent cash commitments. This is the basis of $M$ insky's theory of financial fragility.

Commercial banks face a series of risks, the most important being liquidity or funding risks. Commercial banks fund their lending by borrowing from the public by issuing sight deposits, which may be redeemed at any time. If the bank has lent these funds to a commercial borrower it will have to attract alternative lenders in order to avoid calling in loans. It may not always be able to do so; indeed, its liquidity or refunding risk arises because at times it may lack the liquidity to repay its liabilities and to renew this lending by finding other depositors. If the commercial bank is lending to business it also faces credit risk, for the firms that have borrowed from the bank may not be able to repay on a timely basis. The bank will have become what $M$ insky calls a speculative unit - that is, a unit whose required 
interest payments exceed its earnings - and it will find difficulties in attracting additional deposits. Finally, a bank that funds lending at interest by issuing liabilities on which it has made a commitment to pay interest, must make sure that the positive differential (net interest margin) between the rate on its liabilities and the rate on its assets is maintained. If the term or the reset rate of the interest on the liabilities is shorter than that of the assets, the bank faces market or interest rate risk. Should the rate it has to pay to attract funds exceed the rate at which it has committed to lend, then a loan is subject to net present value reversal, and the bank will make losses and be unable to meet its commitments.

It is thus extremely important for a bank to present itself to its depositors as a hedge-financing unit that is able to make payments to its creditors on demand with perfect certainty. This would seem to imply holding a cash cushion against potential deposit withdrawals of $100 \%$ of the deposits, and this would imply that the bank could do no lending. But commercial banks do make business loans, so the question is how it does this without incurring unmanageable risks. The term "unmanageable" here means without running the risk of becoming a speculative unit and being unable to meet depositors' withdrawal requests. So, although banks will incur both liquidity and credit risks, they seek to make them manageable by fully hedging these risks (K regel $1998 \mathrm{~b}$, ch. 7).

We may see how this might be done by considering an archetypal commercial bank that only makes short-term commercial and industrial loans of less than 90 days that are over-collateralized against goods in warehouse or contracts for sale of outputs. In this case, the value of the loan is some fraction of the anticipated realization value of the collateral. So if a borrower fails to repay, the bank takes possession of the goods and sells them for an amount equal to the value of the loan. $M$ anageability here means making loans that are less than $100 \%$ of the total value of the property pledged as collateral.

Bankers can calculate with reasonable certainty theamount of their total deposits that have to be repaid in the course of any given day. At the same time, banks can arrange their lending so that the total loans repaid each day equals the cash turnover requirement. This minimizes the amount of cash that has to be available to meet cash outflows. Since these calculations are only statistical probabilities, they have a margin of error. Thus bankers maintain a cash cushion or liquidity reserve that can be used when net outflows of funds are positive, as frequently occurs. Usually this reserve against deposits has averaged much less than $10 \%$. When the value of collateral is less than loan value, the bank's owners can if necessary fall back on their capital to make payments to depositors. Thus, for average daily operations a bank can "safely" lend a relatively large multiple of its capital and of its deposits, with its risks fully hedged by the value of the collateral, its cash reserve cushion and the bank owner's capital. As a result, banks are usually very highly leveraged - with gearing and deposit multipliers well in excess of 10 to 1 - without being considered excessively risky. In this way a bank can maintain a hedged balance sheet that protects it from becoming a speculative unit (in M insky's sense).

H owever, hedging the risks of a highly leveraged balance sheet does have an 
opportunity cost, however, since one main source of bank earnings, given a positive lending differential, is the multiple by which the bank can create deposits by lending in excess of the deposits it has borrowed from the public. To increase this ratio beyond that associated with the hedging of risk means increasing the probability that the liquidity and capital cushion will be insufficient to meet repayment requests - and hence the probability that a liquidity crisis and a loss of confidence could produce insolvency due to demands for repayment in excess of reserves and capital resources. Thus banks also face a trade-off between risk and liquidity, which translates into a tradeoff between profitability and liquidity. $\mathrm{N}$ otice that the decision on how to hedge the various risks depends on the subjective perception of these different risks and the values of the collateral pledged against loans; the type and degree of hedging will thus be representative of the bank's liquidity preference. A decision to expand credit lending through additional deposit creation, other things being equal, is thus a decision by the bank to reduce its liquidity cushion and either an explicit decision to increase risk, or a subjective revaluation of the bank's position that reduces the perceived risks faced by the bank or increases the collateral values pledged against loans. For example, a more optimistic evaluation of the resale value of collateral will allow a bank to increase its lending but not its perceived risk. In this case, the reliability of the new estimate of collateral value is crucial.

\section{COM PETITION, REGULATION, AND INNOVATION IN BAN KING}

The two previous sections spell out some of the dynamics of banking behavior, from two complementary theoretical perspectives. How then do banks compete? The first wisdom here is that banks compete differently depending on the state of their own balance sheets and the state of the economy as a whole. When financial institutions are competing aggressively they seek to maximize their market share; but when faced with difficulties they restrict their market expansion and compete for liquidity and/or solvency. As a result, competition in banking carries an inbuilt tendency to underestimate risks when the economy is expanding at a steady and seemingly predictable pace, and to overestimate them when the economy is in decline. It is the former that is more dangerous for the survival of the bank, and that constitutes the banking sector's contribution to the overall uncertainty and instability of the economy as a whole.

To avoid such crises, most countries have introduced formal regulations, in the form of compulsory reserve ratios and minimum capital ratios, which impose bank hedging and thus create uniform standards for bank liquidity. Central banks in some countries have accepted the responsibility of acting as lender of last resort: that is, they stand ready to advance credits against a bank's doubtful assets in an emergency, thereby allowing banks to meet payment commitments even when they are in a speculative position and lack the liquidity to meet depositor withdrawals.

H owever, this governmental oversight has not protected commercial banks 
from competition with other providers of financial services. Indeed, in the past three decades, a competitive struggle has been waged betw een financial institutions facing different types of financial regulation. Banks have lost business to financial institutions that were not so highly regulated. The regulations covering commercial banks have limited their use of financial innovation to protect their deposit base and thus their net interest margin on normal lending activity. Thus, commercial banks have initiated primarily counter-regulatory innovations; and these have led banks to expand their activities in new directions.

This process began in the United States when a credit crunch and regulations on capital flows introduced during 1960s balance of payments and dollar crises created incentives for US banks to shift some of their borrowing operations out of the United States to "off shore" markets, primarily London. In addition to providing new sources of dollar funding for US banks, these markets provided an environment free of the segmentation imposed by US bank regulation. Commercial banks could thus operate internationally much like investment banks in the US, making many US bank global players, dealing in financial assets from around the globe.

Then in the 1970s, savings and loan institutions started to compete with banks by offering to pay interest (and in some cases a free toaster or mink coat) on transactions deposits, while commercial banks remained restricted to zero interest deposit accounts. Since regulations apply to reserve ratios and interest rates payable on deposit funds, banks innovated by seeking new sources of funds not technically classified as deposits. This was the primary source of competitive innovation in the 1970s and early 1980s (M ayer, 1974); competition within classes of depository instruments remains fierce today. W ithin each regulatory class, the competitive pressure is extreme: the products that a bank uses to decrease its required reserves or regulatory capital (and hence increase its earnings) are easily replicated through reverse engineering techniques that are widely known in the markets and sold publicly to clients. ${ }^{7}$

$O$ verall, these shifts have caused banks' most important source of earnings, the net interest margin between borrowing and lending rates, to decline dramatically. To meet earnings shortfalls, commercial banks have been forced into other areas of activity, such as providing financial services to generate fee and commission income, and engaging in proprietary trading of financial assets (K regel, 1996, 1998). These shifts have fundamentally altered bank behavior.

As noted above, proprietary trading by commercial banks requires a different type of information than does conventional lending. Earnings from financial arbitrage are based on the knowledge of prevailing market prices, and of the prices that other financial market participants expect to prevail. This shift toward fee-based income has altered the kind of information that banks collect, and the relative value

\footnotetext{
${ }^{7}$ T wo examples make this point. The negotiable $C D$, offered to business clients by First $\mathrm{N}$ ational City Bank was quickly offered by all commercial banks to their clients. The securitization of bank assets through special purpose vehicles was pioneered by Salomon in mortgage banking after the collapse of the savings and loans, but was soon extended to other assets.
} 
of market-based and firm-based information within banking firms. Further, the introduction of risk-weighted capital-asset ratios led banks to create new types of assets that either have lower risk weightings or do not appear on bank balance sheets at all (hence requiring no capital). The result has been a rash of new product innovation in which banks act as market makers in derivatives products.

These new activities represent substantially different types of risk and different tradeoffs between risks and returns, with a likely overall increase in risk. Proprietary trading, for example, carries large price risks which banks have not traditionally been accustomed to manage (Strange: 1998, chapter 2).

Finally, much bank lending is now securitized into collateralized loan obligations, which banks sell to final investors so as to move loans off their balance sheets. This frees up bank capital; it also generates fee and commission income from booking the loans and from underwriting and selling the securitized packages. Lending to firms is being done increasingly through derivative packages arranged by banks and sold to bank clients, often with banks themselves taking the opposite side of the hedges or providing subsidiary guarantees (that also are off balance-sheet). Thus, the new activities that banks are creating to protect earnings is transforming their package of risks and making it much more difficult to identify appropriate "margins of safety" . O verall, it is readily seen that these innovative products, practices, and strategies in the banking system have not only reshaped, but also deepened, this system's tendency towards financial fragility.

In Schumpeterian terms, continuous product innovation is required for banks to create monopoly profits, conquer new clients, and improve competitive position against other banks. Financial product innovation diffusion occurs almost instantaneously, since patent protection is difficult to attain and information is rapidly diffused (by product imitation) among institutions. Thus, first-mover profits are ephemeral: once created, they almost instantaneously evaporate. Consequently, much competitive innovation has taken the form of rapid bank consolidation: it is easier to buy competitors than to gain a dominant advantage over them, and the gain in size leads to hoped-for gains from economies of scale and scope. Since 1980, consolidation has occurred rapidly both within and across regulatory classes (Dymski, 1999). In 1999, US banking legislation opened the way for consolidation across financial product lines, thus removing the regulatory classifications that have driven much of the competitive activity in the financial sector over the last thirty years.

\section{GLOBALIZATION, FINAN CIAL FRAGILITY AND DEVELOPING COUNTRIES}

\subsection{Exchange R ate Fluctuations and Reinforced Financial Fragility}

H ow is our framework affected when we consider the increasingly important global context? To begin, for firms with a high proportion of imported inputs, 
export sales, or foreign borrowing; depreciation of the exchange rate will have the same effect on cash flow commitments as an increase in interest rates. For countries operating in an open trading system these two exogenous changes usually occur together and reinforce one other, since higher interest rates are often used to stabilize a weak currency after devaluation.

Cash cushions or margins of safety thus are necessarily larger for firms operating in countries with open capital markets and uncontrolled capital flows (K regel, 1997c and 1998a).

For some borrowers, safety cushions will not be large enough to cover exogenous changes in both interest rates and exchange rates; these units may be transformed immediately from "hedge" finance units to "Ponzi" finance units. Shifts that reduce borrowers' cushions of safety also increase lenders' credit risk on their outstanding bank loans. Firms' borrower's risk also increases as they find it more difficult to realize the cash flows they initially expected. 0 verall, the fragility of the domestic financial system increases with either a rise in interest rates, or a depreciation of the currency.

O bviously, this same reasoning can be applied to domestic banks that borrow or lend in international capital markets. They will require higher cushions of safety against possible changes in international interest rates or in exchange rates. A bank with international operations is also exposed because a rise in interest rates and depreciation of the exchange rate also reduces the present value of its cash flows from domestic assets (represented by the interest payments received from its outstanding domestic loans), increases the interest costs of its foreign funding, and reduces the credit quality of its domestic loans. Any of these shifts reduce the bank's credit rating as a borrower, and force it to pay higher credit spreads on its domestic and international funding. If the change in rates is sufficiently large, banks may also find themselves suddenly in the condition of a Ponzi unit; in this case, banks' net present values fall below zero and institutions in this position become technically insolvent.

Banks' response to such conditions - especially if their own funding sources refuse to roll over or extend credits - is to reduce lending to firms that are classified as hedge and speculative units, and calling in loans to Ponzi financing units. If domestic banks are also unwilling or unable to lend, the domestic inter bank market will also contract, and a generalized liquidity shortage will arise. As both firms and banks attempt to reduce their foreign currency exposure, a breakdown in the foreign exchange market may also occur. In this manner, cross-border financial linkages can readily transform a financially fragile system into a financially unstable system.

The consequences of these financial shifts can be dire. As noted, the special characteristics of speculative and Ponzi firms is that they need increased finance from the banks just to stay in business. In such conditions, Ponzi financing firms have no choice but to reduce their own cash outflows, delaying current payments to suppliers, cutting back on expenditures, and by attempting to raise cash in any way possible - selling out inventories and any output they can produce at dis- 
tress prices. If these measures are not sufficient to cover their cash flow needs, they will be forced to suspend investment projects, sell other assets, and layoff or fire workers.

A ny number of factors, and not just shifts in exchange rates, can generate the scenario just outlined: among these are the tendency toward underestimation of risks in periods of sustained economic stability, periods of epochal Schumpeterian technological changes which increase optimism regarding the profit potential of new technologies, and so on. Significant balance-sheet exposure to foreign markets - either through loans or goods - reduces the size of the external shock required to trigger financial stress. Further, a period of prolonged exchange rate stability may in itself lead to over-optimism regarding the stability of the domestic currency values of foreign commitments, tempting units to reduce the margins of safety they maintain on foreign commitments. This endogenous change in margins makes the passage from a fragile to an unstable system that much more rapid in the event of an exogenous shock.

H owever, every period of tranquility and every technological revolution is interrupted; so expectations are eventually disappointed, challenging financial and non-financial units alike. In M insky's model, this spread of fragility from the productive to the banking sector characterizes the passage from financial fragility to financial instability and crisis.

\subsection{The Special Fragility of Developing C ountries.}

M insky's original analysis of the passage from financial fragility to financial instability focused on changes in domestic monetary policy or the persistence of stable domestic conditions. This analysis is easily extended to the open economy case of an exogenous exchange rate shock, which affects companies operating in open trading systems and banks borrowing and lending in international money and capital markets. With increasingly interdependent capital markets and increased capital flows, the analysis of changes in monetary policy should be extended to encompass changes in the monetary policy of the largest international lenders.

Changes in interest rates of the major international lenders, especially the US and Japan, have been especially important in creating financial instability in developing countries during the debt crises of the 1970s and 1980s; their impact on exchange rates has been a major factor in the 1997 A sian financial crisis. H owever, that crisis was exacerbated by an additional element: the conditionality imposed on the borrowers seeking support from the multilateral agencies (K regel, 1998).

As noted above, the normal scenario for a developing country financial crisis involves domestic firms borrowing in foreign currency from foreign banks at interest rates that are reset at a short rollover period. $N$ ote that it makes little difference if the loans have a short or long maturity; the point is the change in interest costs on cash flows produced by the short reset interval for interest rates. Short reset periods mean that a rise in foreign interest rates is quickly transformed into 
an increased cash-flow commitment for the borrower, instantly reducing margins of safety. If the change in international interest rate differentials leads to a depreciation of the domestic currency relative to the borrowed foreign currency, then the cushion of safety is further eroded by the increase in the domestic currency value of the cash commitments and the principal to be repaid at maturity.

Developing-country governments sometimes respond to the weakness of the domestic currency in international markets by increasing domestic interest rates, with the aim of stemming currency speculation or increasing foreign demand for the currency; how ever, such policy steps adversely affect domestic demand, reduce domestic cash flows, and increase domestic financing costs. Firms may thus pass rapidly from hedge financing to Ponzi finance units as the result of a rise in foreign interest rates. Whether this increase in financial fragility turns to instability and crisis depends on the willingness of foreign banks to extend additional foreign currency lending to cover payment shortfalls on current commitments. If foreign banks follow the bankers' aphorism, they may be unwilling to do this.

As a result, firms may be forced to try to improve their foreign earnings by increasing foreign sales. But this usually leads to falling prices in international markets, compounding losses from depreciation of the exchange rate; any cutback in domestic operations simply makes domestic demand conditions worse. The knock-on or contagion effect thus hits both the domestic financial system and the foreign banks, which now have increasingly dubious loans on their books. If foreign and domestic banks' capital cushion is insufficient to absorb the losses, then fragility turns to global systemic instability. In any case, the initial shock and the recommended policies combine to increase fragility and thus make instability possible in any exchange rate crisis.

\section{CONCLUSION : PERSPECTIVES ON FINAN CIAL POLICIES AND DEVELOPMENT}

In Schumpeter's view, economic growth requires that the financial system provide a means for the most dynamic entrepreneurs to obtain resources from the dying, static parts of the economy, in a process he called "creative destruction". Schumpeter's student M insky agreed that the financing of innovation is a core element in economic growth. This implies, as argued above, that a banking system capable of identifying knowledge-based innovation and supporting it through credit- and capital-market outlays. At the same time, the framework has shown that the macrodynamics of open capitalist economies tend to endogenously generate financial fragility, and that banking competition has shifted the information that banks rely on to generate revenue away from detailed understanding of borrower firms' capacity and toward price movements in financial markets. In other words, the banking relations that Schumpeter viewed as crucial in supporting growth are threatened by current global trends.

What the above discussion tried to show was that from the point of view of 
Schumpeterian "creative destruction" or M inskyian "endogenous financial fragility" a certain amount of evolutionary instability is necessary to allow the competitive innovation that makes the system viable. When banks and other financial institutions provide the financial resources that lead to successful innovation by some firms, they will also be financing firms whose competitive strategies are unsuccessful. Perfectly safe and stable banks would mean stagnant economic development. It thus seems clear that the major objective of policy cannot be the elimination of change and instability, for this would eliminate economic development. Rather, policy should be directed towards ensuring financing of innovative capital projects.

The role of financial policy when saw from a development perspective should be, therefore, to prevent the endemic systemic instability that can cause reversals of capital flows and changes in financial prices (and lead to M insky-Fisher debt deflations) by providing for appropriate integration of financial institutions and markets. This would involve several major areas. 0 ne is risk management. As seen above, the major activity of banks is risk management, not undertaking the risks of maturity mismatches. A second policy focus should be on monitoring the manner in which risks are shifted from financial institutions to other balance sheets, primarily those of the public. This puts emphasis on the provision of market liquidity. H ouseholds will be more willing to hold long-term assets if some of their price risk is offset by their ability to sell these assets at short notice in liquid markets. This liquidity, in turn, depends on the activity of financial institutions serving as market makers, either directly or indirectly. Their ability to make markets depends on their financing, in particular on their gearing or leverage ratios. In sum, policy must focus on risk management techniques of financial institutions, the manner in which this risk management shifts risks to balance sheets outside the financial sector, the provision of market liquidity, and the degree of leverage of balance sheets. Finally, these considerations suggest that developing countries should be given the means to mold national financial structures which best facilitate the growth of knowledge-absorbing sectors (C hristensen, 1992, $\mathrm{N}$ elson, 1993, Bresser-Pereira, 2004), given their economic and social structures, their historical trajectories, and their institutional inheritances. ${ }^{8}$ But this does not mean that each nation will be able to identify a single financial model that facilitates growth and minimizes risks at every point in its development process $G$ row th requires financing, and both the process of growth and the process of financing growth are inherently volatile and unstable, as both Schumpeter and M insky emphasized.

\footnotetext{
${ }^{8}$ For instance, as Bresser-Pereira states in a forthcoming preface: the exchange rate is the most strategic of the four macroeconomic prices. It determines not only exports and imports, but also real wages, consumption and the savings rate. Conventional theory holds that it is impossible to manage it, and that the only alternatives are to fix or to float it. The experience of the East A sian countries, that use it strategically, demonstrates that this claim is false (Bresser-Pereira, 2004, p. 1).
} 


\section{REFEREN CES}

ARTHUR, B. (1994): Increasing Returns and Path D ependence in the E conomy. M ichigan University Press

BEST, M . (1990): The N ew Competition. H arvard Univ. Press.

BEST, M . (2001): The N ew Competitive A dvantage. Oxford University Press.

BRESSER-PEREIRA, L. C. (2004) “Exchange R ate: fix, float, or manage it?", Preface to M athias Vernengo, ed. Financial Integration or D ollarization: N o Panacea. Cheltenham: Edward Elgar.

CHAN DLER, A. (1990): Scale and Scope, Cambridge, M ass. The Belknap Press of H arvard University Press.

CHAN DLER, A., AM ATORI, F. and HIKIN O, T. (1997): Big Business and the Wealth of N ations. Cambridge University Press.

CHRISTEN SEN , J.L. (1992): "The R ole of Finance in N ational Systems of Innovation" in Lundvall, B. A., ed. N ational Systems of Innovation. Pinter.

DAVID, P. (1985): "Clio and The Economics of QWERTY" in American Economic Review, Vol. 75 (M ay).

DORE, R (2000): Stock M arket Capitalism / W elfare Capitalism -Japan and G ermany versus the Anglo-Saxons. Oxford Univessity Press.

DY M SKI, G. (1999): The Bank M erger Wave: The E conomic Causes and Social Consequences of Financial Consolidation. Armonk, NY: M.E. Sharpe.

FREIXAS, X avier and ROCHET Jean-Charles. (1997): The M icroeconomics of Banking. Cambridge, MA: M IT Press.

H AM M ON D, B. (1967): Banks and Politics in America, Princeton University Press.

KEY N ES, J. M . (1936 [1985]): The G eneral Theory of Employment, Interest and M oney. M acmillan.

KREGEL, J. A . (1992): "Universal Banking, US Banking R eform and Financial Competition in the EEC", Banca N azionale del Lavoro Q uarterly R eview, oo 182, September, 1992, pp. 231-54.

KREGEL, J. A., (1995): "M arket Form and Financial Performance", E conomic N otes, Vol. 24, no 3, 1995, p. 485-504.

KREGEL, J. A. (1996): O rigini e sviluppo dei mercati finanziari. A rezzo: Banca Popolare dell'Etruria e del Lazio.

KREGEL, J. A. (1997): "M argins of Safety and W eight of the Argument in Generating Financial Fragility" , J ournal of Economic I ssues, June, pp. 543-8.

KREGEL, J. A. (1998a): "Yes, 'It' Did H appen A gain - A M insky Crisis H appened in A sia", J erome Levy Institute W orking Paper.

KREGEL, J. A . (1998 b): The Past and Future of Banks, Ente per gli Studi M onetari, Bancari e Finanziari Luigi Einaudi, Q uaderni di Ricerche, № 21, Rome, Bank of Italy.

LAZO N ICK,W. (1991): Business O rganization and the M yth of the M arket E conomy, Cambridge University Press.

LITAN, Robert (1987): What Should Banks D o?, Washington, D.C.: Brookings Institution.

M ADELEIN E, M . G. (1943): M onetary and Banking Theories of J acksonian D emocracy, Philadelphia.

M AYER, M . (1974): The Bankers, N ew Y ork: Ballantine Books.

M AYER, M . (1988): M arkets, N ew Y ork: N orton.

M AYER, M .(1992): Stealing the M arket, N ew York: Basic Books.

M IN SKY, H . (1978): "The Financial Instability H ypothesis: An Interpretation of Keynes and an AIternative to Standard Theory", in M insky, H . (1982).

M IN SKY, H . (1982): Can "IT" H appen A gain: Essays on Instability and Finance, Armonk, M. E. Sharpe.

M IN SKY, H . (1986): Stabilizing an Unstable Economy, N ew H aven and London: Yale Univ. Press.

M IN SKY, H . (1990): "Schumpeter: M oney and Evolution" in H eertje and Perlman, (eds.): Evolving Technology and M arket Structure - Studies in Schumpeterian Economics. M ichigan University Press.

M ORRIS, Charles R. (1999). M oney, G reed, and Risk: Why Financial Crises and Crashes H appen, $\mathrm{N}$ ew $\mathrm{Y}$ ork: Times Busines Random $\mathrm{H}$ ouse. 
NELSO N , R. and WINTER, S. (1982): An Evolutionary Theory of Economic Change, H arvard University Press.

NELSO N, R. (ed) (1993): N ational Systems of Innovation. Oxford University Press.

PEN ROSE, E. (1995 [1959]): The Theory of the G rowth of the Firm, O xford University Press.

PIERCE, James L. (1991): The Future of Banking, A Twentieth Century Fund Report, $\mathrm{N}$ ew Haven: Y ale University Press.

ROBERTSO N, R. M . (1955): H istory of the A merican Economy, N ew Y ork: H arcourt Brace.

ROBERTSO N , R. M . (1964): H istory of the A merican Economy, 2nd ed. N ew Y ork: H arcourt Brace.

SCH UM PETER, J. (1997 [1934]): The Theory of Economic D evelopment, Transaction Publishers.

STRAN GE, S. (1998): M ad M oney. M anchester University Press. 